\title{
Seasonal variation in sedimentation of organic materials in the St. Lawrence Island polynya region, Bering Sea
}

\author{
Lee W. Cooper ${ }^{1, *}$, Jacqueline M. Grebmeier ${ }^{1}$, Inguar L. Larsen ${ }^{2}$, Victor G. Egorov ${ }^{3}$, \\ Chris Theodorakis ${ }^{4}$, Holly P. Kelly ${ }^{1}$, James R. Lovvorn ${ }^{5}$ \\ ${ }^{1}$ Department of Ecology and Evolutionary Biology, 569 Dabney Hall, University of Tennessee, Knoxville, Tennessee 37996, USA \\ ${ }^{2}$ Teledyne Brown Engineering, 108 Quality Lane, Knoxville, Tennessee 37931, USA \\ ${ }^{3}$ Institute of Energy Problems of Chemical Physics (Branch), 142432 Chernogolovka (Moscow Region), Russia \\ ${ }^{4}$ Institute of Environmental and Human Health, Texas Tech University, PO Box 41163, Lubbock, Texas 74049-1163, USA \\ ${ }^{5}$ Department of Zoology, University of Wyoming, Laramie, Wyoming 82071, USA
}

\begin{abstract}
A polynya that forms each winter south of St. Lawrence Island in the Bering Sea is located near very high standing stocks of macrobenthic invertebrates on this Arctic continental shelf. Sampling during or just after the ice melt in 1990, 1993, and 1994 revealed water-column, sediment particle and chemical distributions that were consistent with a high flux of organic materials to the sediments during the ice retreat. In contrast, lower phytoplankton biomass observed in late summer and fall of 1993, 1998, and 1999 was associated with seasonal declines in sedimentation indicators such as chlorophyll $a$ in the water column and deposited on the surface sediments, lower occurrences of an atmospherically derived radionuclide beryllium-7 $\left({ }^{7} \mathrm{Be}\right)$ in surface sediments, and lower sediment oxygen demand. Moreover, observations under late-winter conditions in April 1999 did not support a direct, continuous linkage between water-column production when the winter polynya is active and the very high benthic biomass and productivity observed on this shallow (30 to $60 \mathrm{~m}$ ) shelf. For example, deposition of recent water-column production to the sediments in April was significantly lower than that during and just after the ice retreat in May and June. This lower rate of deposition in April was inferred from proxy indicators including photosynthetically-competent chlorophyll extractable from surface sediments, the presence of ${ }^{7} \mathrm{Be}$ in surface sediments, and sediment oxygen demand. Despite high nutrient concentrations, water-column chlorophyll a concentrations were also uniformly lower $\left(0.5\right.$ to $\left.2 \mathrm{mg} \mathrm{m}^{-3}\right)$ in April than in May and June. Measurements of the underwater light and ultraviolet radiation field and analysis of DNA damage to dosimeters indicated that the low chlorophyll a biomass is probably not influenced by UV radiation in late winter and early spring. The stable carbon isotope composition of organic carbon in surface sediments suggests that open-water production in the polynya, relative to the adjacent production of sea-ice algae, is not large enough to influence the isotopic composition of organic materials in surface sediments near the polynya.
\end{abstract}

KEY WORDS: Bering Sea · Polynya $\cdot$ Benthic-pelagic coupling $\cdot$ Beryllium-7 $\cdot$ Ultraviolet radiation · Carbon isotopes

Resale or republication not permitted without written consent of the publisher

\section{INTRODUCTION}

The term polynya is of Russian etymology, and describes recurring ice-free areas in otherwise ice-

*E-mail: lcooper1@utk.edu covered polar seas that are often associated with large populations of marine mammals and birds (Massom 1988, Stirling 1997, Solovieva 1999, Gilchrist \& Robertson 2000) and high biological productivity (Smith \& Gordon 1997). A polynya forms each winter south of St. Lawrence Island in the Bering Sea in shallow water 
(30 to $50 \mathrm{~m}$ ), over a soft-bottom continental shelf with some of the highest benthic biomass in the Arctic (Grebmeier \& Cooper 1995). This polynya is a winteronly feature when the Bering Sea is ice-covered, and is influenced by wind speed and direction. It varies in median area from $2000 \mathrm{~km}^{2}$ in January and February to $3000-4000 \mathrm{~km}^{2}$ in March and April (Stringer \& Groves 1991). By May, it can increase in size to as much as $16000 \mathrm{~km}^{2}$, forming a continuous body of open water with portions of the Bering Sea as the ice recedes. Depending upon wind speed and direction, the polynya can also disappear during the winter (Smith et al. 1990). Physical processes, including baroclinic flow associated with brine injection during seaice formation, appear to influence the distribution of organic-rich materials deposited to the sea floor (Grebmeier \& Cooper 1995). Furthermore, the high biomass of macrobenthic invertebrates here is clearly important to benthic-feeding apex predators, including fishes, crabs, walrus, spectacled eiders, and gray whales (Fay et al. 1977, Feder \& Jewett 1981, Grebmeier \& Harrison 1992, Highsmith \& Coyle 1992, Petersen et al. 1998).

A remaining unknown, however, is the extent to which pelagic production in the ice-free waters of this winter-only polynya enhances benthic organic deposition by allowing an earlier start to pelagic watercolumn production. Published observations of latewinter biological conditions in this region of the Bering Sea are sparse or non-existent. However, the waters of the western Bering Sea are consistently nutrient-rich, with high biological productivity throughout the openwater season (Walsh et al. 1989). Nutrient-rich waters are brought into the polynya region as northwardflowing Anadyr Water, some of which is advected to the south of St. Lawrence Island rather than passing north and west of the island towards the Bering Strait (Grebmeier \& Cooper 1995, Cooper et al. 1999). Thus, when the Bering Sea is ice-covered in late winter (March and April), open water south of St. Lawrence Island may support relatively high primary productivity and subsequent organic deposition to the shallow benthos in the presence of increasing sunlight and high nutrients. Consequently, we sought to resolve the following question: is there a higher deposition of marine organic particles to the benthos in the polynya region during late winter when the polynya is present, than in the ice-free period from June to November?

Our study of organic deposition to the benthos in late winter versus summer required sediment and watercolumn indicators that would be only temporally persistent or would reflect differences in winter polynya/ice edge and summer open-water production. Because the system is shallow and resuspension of particles likely, sediment-trap technologies were precluded as a possible research approach. Instead, we used data from both the water column and sediments, including water-column chlorophyll $a$ as a precursor to sedimentation over the shallow shelf during each of the months between April and September (late winter to fall). Water-column concentrations of chlorophyll $a$, integrated over the entire water column reflect pelagic organic carbon particle distributions prior to deposition. Although in other oceanic systems fluxes of primary production to the sea floor can be modified significantly by zooplankton grazing, at the Bering Sea ice edge primary production and the underlying shallow continental shelf lead to deposition of a high proportion of primary production directly to the benthos (Cooney \& Coyle 1982, Coyle \& Cooney 1988). The current flow regime in the region south of St. Lawrence Island also leads to local deposition of organic materials. Current flow is sluggish in the winter, reflecting a balance between northward water flow on the Bering Shelf that is blocked by St. Lawrence Island, and southward baroclinic flow along the sea floor that is driven by brine injection in the polynya when ice is formed (Smith et al. 1990). These physical and trophic factors suggested to us that seasonal comparisons of water-column distributions of chlorophyll $a$ integrated over the whole water column would reliably predict the appearance or intensity of sedimentation indicators as organic particles reach the sea floor.

In related efforts, we measured the underwater light and ultraviolet radiation field when the winter polynya was present and, through DNA dosimeter damage, evaluated whether UV radiation has any potential influence on primary production in late winter and early spring. Increased UV fluxes have been observed in the late winter-early spring period in the Arctic as a result of anthropogenic and natural contributions of ozone-depleting halons, and these could have a deleterious effect on production of organic materials. Consequently, we incorporated UV, and UV-specific DNAdamage measurements into our study to assess their potential influence upon primary production in the late-winter polynya.

Our chosen sediment indicators comprised: (1) the presence of the short-lived (half life $=53 \mathrm{~d}$ ), atmospherically-derived, particle-reactive radionuclide ${ }^{7} \mathrm{Be}$ in surface sediments; (2) an inventory of photosynthetically competent chlorophyll $a$ in the surface sediments; (3) sediment oxygen demand; (4) the stable isotope composition of organic carbon in the surface sediments. These sedimentary parameters were selected for the following reasons: the only natural source of ${ }^{7} \mathrm{Be}$ is its generation in the atmosphere following cosmic ray spallation of nitrogen and argon. This isotope has a short half-life and the element has a short chemical residence time in seawater because of its chemical reactivity with marine particles (Olsen et al. 1986). Therefore, surface bottom-sediments in which 
this radionuclide are detected must be regions where there has been recent particle deposition from the sea surface. Similarly, the concentration of photosynthetically competent chlorophyll $a$ in surface sediments is a proxy indicator of recent organic deposition in sediments (Dayton \& Oliver 1977, Dayton et al. 1986, Ambrose \& Renaud 1995). Once organic materials have reached the sea floor and have been acted upon by meio-, macro- and mega-fauna, measurements of sediment oxygen demand, whether accomplished in situ or during shipboard incubations, provide another indication of recent (previous weeks to months) organic carbon deposition (Grebmeier \& Cooper 1995).

We also hypothesized that the stable carbon isotope composition of organic carbon in sediments underlying the polynya region could also indicate the importance of open-water primary production. We expected sedimentary organic carbon derived from open-water withinpolynya production to have relatively more negative $\delta^{13} \mathrm{C}$ values than sedimentary organic carbon derived from production of sea-ice algae (Rau et al. 1991, Hobson et al. 1995). We recognize that other factors are also likely to influence the carbon isotope composition of organic material in the Bering Sea. These factors include terrestrial contributions and kinetic isotopic fractionation of inorganic carbon acquisition during photosynthesis (see for example discussions in Fry 1996, Rau et al. 1997, Korb et al. 1998, and Riebesell et al. 2000). However, a compilation of organic carbon isotope data for sediments throughout the Amerasian Arctic (Naidu et al. 2000) has facilitated evaluation of the importance of ice algae and open-water production in specific regions such as the St. Lawrence Island polynya. We hypothesized that if primary production in the polynya has a significant influence on the annual particle flux to the benthos, then underlying the shallow polynya should be a distinct umbra of isotopically lighter organic carbon deposit on the sediments. This also assumes that ice-algae production and deposition is cumulatively significant, with carbon deposition outside the boundaries of the polynya reflecting less negative $\delta^{13} \mathrm{C}$ values associated with sea-ice algae production. sured using an AU-10 fluorometer (Turner Designs, Sunnyvale, CA) The traditional acidification assay was used on cruises up to 1994; after that time, chlorophyll determinations were made with a Turner Designs AU10 fluorometer equipped for measurements using the non-acidification assay described by Welschmeyer (1994). Calibration of the fluorometer on all cruises used certified standards.

UV radiation. On 2 cruises, in September 1998 and April 1999, we deployed a molecular DNA dosimeter system for quantifying UV damage in conjunction with measurements made by a commercially available, submersible UV radiometer (Biospherical Instruments PUV 510, San Diego, CA). Several DNA dosimeter designs are in use (see for example Regan et al. 1992 and Yoshida \& Regan 1997). We used purified DNA (Colliphage T7, Sigma-Aldrich, St. Louis) dissolved in a stabilizing phosphate buffer $(\mathrm{pH}$ 8.0, $50 \mathrm{mM}$ phosphate, $200 \mathrm{mM} \mathrm{KCl}, 10 \mathrm{mM}$ EDTA) at a concentration of $60 \mu \mathrm{g} \mathrm{ml}^{-1}$. An aliquot of $375 \mu \mathrm{l}$ was placed in a UV-transparent quartz-glass cuvette, flame-sealed, and kept in the dark and under refrigeration until exposure. A hook was incorporated into the quartz-glass cuvette to allow the attachment of the dosimeter to nylon fishing-filament line.

During each exposure, the cuvettes were attached to the nylon fishing line, weighted with lead, and deployed by hand into sun-lit waters from 2 research vessels in the Bering Sea, in September 1998 (RV 'Alpha Helix') and April 1999 (USCGC 'Polar Sea'). Exposure depths ranged from 0 to $5 \mathrm{~m}$, including dosimeters exposed on the ship deck as well as at the water surface. Several dosimeters were used as controls, either being kept in the dark or exposed only to the longer UV-A band ( 320 to $380 \mathrm{~nm}$ ) through the use of a Mylar filter. During dosimeter exposure, continuous surface UV measurements were made every $60 \mathrm{~s}$ with a ship-mounted radiometer. The linked submersible meter was deployed hourly (measurements made each second) during exposure of the dosimeters, to measure the dependence of exposure upon water depth. The UV measurement technology employed by the instrument package is

\section{MATERIALS AND METHODS}

The data presented herein were collected on a number of different cruises in the region in and near St. Lawrence Island (Table 1) during the period 1988 to 1999.

Water-column chlorophyll a. Water samples $(250 \mathrm{ml})$ from up to 12 depths at each station were filtered through Whatman GF/C filters and extracted in $90 \%$ acetone, and chlorophyll a concentrations were mea-
Table 1. Cruises that served as sources of data for this study

\begin{tabular}{|lll|}
\hline Ship & Cruise & Date \\
\hline MV 'Akademik Korolev' & BERPAC-1988 & August to September 1988 \\
RV 'Alpha Helix' & HX 139 & June 1990 \\
MV 'OKEAN' & BERPAC-1993 & August to September 1993 \\
RV 'Alpha Helix' & HX 171 & June 1993 \\
RV 'Alpha Helix' & HX 177 & May and June 1994 \\
RV 'Alpha Helix' & HX 214 & September 1998 \\
USCGC 'Polar Sea' & SLIP 1999 & April 1999 \\
RV 'Alpha Helix' & HX 224 & September 1999 \\
\hline
\end{tabular}


filter-based, with measurements at 305, 320, 340 and $380 \mathrm{~nm}$, as well as of photosynthetically active radiation (PAR). Data were compiled with a laptop computer. Additional information on instrument performance is given in Kirk et al. (1994).

After exposure, all dosimeters were returned to the laboratory for analyses, and refrigerated on ice and in the dark. From each dosimeter, $7.5 \mu \mathrm{l}$ of the DNA solution was mixed with $1 \mu \mathrm{l}$ of UV-endonuclease extract (Carrier \& Setlow 1970), and incubated at $37^{\circ} \mathrm{C}$ for $1 \mathrm{~h}$. Other sample aliquots were incubated without adding the enzyme extract. The UV-endonuclease produces a single-strand nick in the DNA adjacent to each thymine-thymine dimer. The DNA was then subjected to electrophoresis on an alkaline agarose gel (pH 12.5), allowing the DNA fragments to unwind and separate for quantification of single-strand breaks. The gel was stained with ethidium bromide and photographed under UV light. The average molecular length of the DNA fragments was calculated from the photograph using the methods of Freeman et al. (1986). Since thymine-thymine dimer formation is a specific result of UV exposure in the UV-B band, we expected that the number and the inverse size of the DNA fragments formed would be proportional to the UV-B flux. A densitometer was used to calculate the number of single-strand breaks and, hence, UV-induced thymine-thymine dimers formed in each sample.

The radiation intensities measured at each waveband by the radiometer were used to calculate biologically weighted UV-B doses (Dahlback 1996) using a DNA action spectrum (Setlow 1974), as recommended by Biospherical Instruments (1997), whereby the DNA dose, $D_{\mathrm{g}}$, is estimated as:

$$
D_{\mathrm{g}}=E 305 a_{1}+E 320 a_{2}+E 340 a_{3}
$$

where $E 305, E 320$, and $E 340$ correspond to the radiation intensity $\left(\mu \mathrm{W} \mathrm{cm}{ }^{-2}\right)$ at the specified wavelength, and the coefficients $a_{1}, a_{2}$, and $a_{3}$ are empirically determined values, 0.07226, -0.00216 , and 0.0008351, respectively.

These coefficients essentially weight the DNA damage associated with each UV band measured by the filter-band instrument and are derived from a comparison of the radiometer with a high spectral resolution instrument in San Diego, CA (Biospherical Instruments 1997). The DNA dose is integrated therefore in $\mathrm{mJ}$ $\mathrm{cm}^{-2}$, taking into account that damage to DNA is not proportional to the total energy exposure but rather the total energy associated with specific wavebands. Thus we report our derived estimate of the DNA dose in units of $\mathrm{mJ} \mathrm{cm}^{-2}$, weighted for the UV-damaging bands.

Beryllium-7. Surface sediments were collected from $0.1 \mathrm{~m}^{2}$ van Veen grabs, and packed in 500 to $1000 \mathrm{ml}$
Marinelli beakers, or from the surface of a $133 \mathrm{~cm}^{2}$ HAPS corer and packed in $90 \mathrm{ml}$ aluminum cans. These sediments were assayed for gamma emitters, including ${ }^{7} \mathrm{Be}$, using low-level, high resolution, lithiumdrifted germanium or high-purity germanium detectors equipped with a Canberra Genie personal computer system (Canberra Industries, Meriden, CT) programmed to record gamma spectra data in 4096 channels. Calibration of the detectors was performed using standards that are traceable to those used at the US National Institute of Standards and Technology. Data on other gamma emitters we detected, specifically ${ }^{137} \mathrm{Cs}$, have been reported elsewhere (Cooper et al. 1998).

Sediment chlorophyll a. Duplicate $1 \mathrm{~cm}^{3}$ surface sediment samples $\left(1.54 \mathrm{~cm}^{2}\right.$ surface area) were collected from the top of the van Veen grab prior to opening the grab. Ten $\mathrm{ml}$ of $90 \%$ acetone was mixed with each sediment sample, which was stored at $4^{\circ} \mathrm{C}$ for $12 \mathrm{~h}$ to ensure extraction of all chlorophyll $a$ within each sediment sample. The chlorophyll a concentration within the acetone extract was then measured with the Turner Designs 10-AU fluorometer, as described above for water-column samples. The mean of 2 chlorophyll a measurements for each station was converted to chlorophyll a per $\mathrm{m}^{2}$ of surface sediments.

Sediment oxygen demand. Duplicate sediment cores for shipboard incubations were collected using a HAPS benthic corer with removable Plexiglas ${ }^{\circledR}$ insert sleeves $\left(133 \mathrm{~cm}^{2}\right.$ surface area; design derived from Kanneworff \& Nicolaisen 1973). Under optimal conditions, the cores recovered were 15 to $25 \mathrm{~cm}$ deep, with a very low degree of apparent disturbance. Our criteria for determining low core disturbance during collection included the presence of clear water at the sediment-water interface, the presence of flocculent materials such as fecal pellets at the base of benthic burrows at the sediment surface, and continued filtering activity by macrobenthic invertebrates. We have also observed that the shortlived, atmospherically derived radionuclide ${ }^{7} \mathrm{Be}$ (discussed above) is not present below the first $1 \mathrm{~cm}$ of the surface in numerous HAPS cores we have counted. Sediment-flux measurements for dissolved oxygen followed the methods of Grebmeier \& McRoy (1989). Bottom water for these experiments was collected with a bottom-triggered 51 Niskin bottle or, in some cases, from bottom-water bottles on the CTD rosette. Enclosed sediment cores with motorized paddles were maintained in the dark at in situ bottom temperatures for approximately $12 \mathrm{~h}$. The temperature of the incubations varied slightly $\left(-1\right.$ to $\left.2^{\circ} \mathrm{C}\right)$, depending upon the time of year, using in situ bottom water CTD measurements as a guideline. Point measurements were made at the start and end of the 
experiment, and flux measurements were calculated, based on concentration differences adjusted to a daily flux per $\mathrm{m}^{2}$. Previous shipboard measurements using real-time probe measurements in these cores at similar sites indicated a steady decline in oxygen values in the overlying water during the course of the incubation. Sediments were sieved upon completing the experiment to determine faunal composition. These biological data and other flux measurements, including alkalinity, $\mathrm{pH}$, and nutrients will be reported elsewhere.

Stable organic carbon isotope ratios of sediments. Surface sediments were collected using a van Veen grab in which sediments were removed from the top of the grab prior to opening it. Sediments were dried at $60^{\circ} \mathrm{C}$, acidified with $0.1 \mathrm{~N} \mathrm{HCl}$ to remove inorganic carbonates, and then combusted in vacuo within sealed Vycor® glass in the presence of cupric oxide, copper metal and silver foil at $850^{\circ} \mathrm{C}$. Carbon dioxide that was generated was separated cryogenically, and was measured by mass spectrometry using a VG SIRA Series II stable isotope mass spectrometer. Precision was $\pm 0.2 \%$, and the data are reported as $\delta^{13} \mathrm{C}$ values relative to the international V-PDB standard.

\section{RESULTS}

\section{Water-column chlorophyll a}

In general, water-column chlorophyll a concentrations were highest during the May, June 1994 RV 'Alpha Helix' cruise made during the sea-ice retreat, and lowest during the April 1999 USCGC 'Polar Sea' cruise made prior to any major ice melt (Fig. 1). Somewhat lower concentrations were observed in the early summer cruises in 1990 and 1993 during the openwater season following ice retreat, and even lower concentrations were observed in the late-season cruise in September 1999 (Fig. 1).

\section{UV radiation}

We estimated total DNA doses at the water surface and at depth by integrating the available hourly or continuous measurements at each depth or at the surface over the exposure period (Table 2). These estimated doses were significantly correlated to the numbers of thymine-thymine dimers formed during the 2 experimental deployments (Fig. 2). Maximum surfaceradiation fluxes were slightly higher during the Dutch Harbor deployment (Fig. 3a; 24 September 1998) than during the deployment south of St. Lawrence Island (Fig. 3b; 21 April 1999). Penetration of damaging UV fluxes into the water column decreased to negligible levels within a few meters of the sea surface in the polynya on a sunny day in April 1999 (Fig. 4).

\section{Beryllium-7}

Activity measurements of the radionuclide ${ }^{7} \mathrm{Be}$ in surface sediments were made on 4 cruises: in April 1999, May and June 1994, June 1993, and September 1998, from late winter to fall. Data from the June 1990 cruise have been reported previously as activities per unit area (Grebmeier \& Cooper 1995). On a dry weight basis, detection limits for the radionuclide were $<1 \mathrm{~Bq} \mathrm{~kg}^{-1}$, and samples were typically counted within $45 \mathrm{~d}(\sim 1$ half-life) of collection. We used 4 available gamma counters to count separate samples simultaneously. Total activities, decay-corrected to the date of collection, were all in the range 0.5 to $21.3 \mathrm{~Bq} \mathrm{~kg}{ }^{-1}$. Counting errors $( \pm 1 \sigma)$ for individual samples were typically 10 to $30 \%$. Generally, higher activities were observed on the early summer cruises, HX 171 (mean = 7.6 Bq kg-1 $\pm 4.6 \mathrm{SD}$ ) and HX 139 $\left(\right.$ mean $\left.=5.7 \mathrm{~Bq} \mathrm{~kg}^{-1} \pm 2.4 \mathrm{SD}\right)$, which followed the peak annual phytoplankton bloom. Generally, lower activities were observed in the late winter on SLIP 1999 (mean $\left.=1.2 \mathrm{~Bq} \mathrm{~kg}^{-1} \pm 0.8 \mathrm{SD}\right)$, during spring on HX 177 (mean $=1.5 \mathrm{~Bq} \mathrm{~kg}^{-1} \pm 0.2 \mathrm{SD}$ ) and during the fall on $\mathrm{HX}$ 214 (mean $\left.=0.7 \mathrm{~Bq} \mathrm{~kg}^{-1} \pm 0.2 \mathrm{SD}\right)$. Because of the low activity levels observed, the long counting times (2 to 3 d) required, and the radionuclide's short-half life, we concluded that reporting simple detection of the radionuclide would be more meaningful than specific activities and associated errors for individual cruises. We therefore present the data as presence or absence

Table 2. Estimated UV DNA dose, using continuous (surface) and profiling (hourly) Biospherical Instruments radiometer data during 2 deployments of DNA dosimeters in the Bering Sea

\begin{tabular}{|cc|}
\hline Water depth $(\mathrm{m})$ & DNA dose $\left(\mathrm{mJ} \mathrm{cm}^{-2}\right)$ \\
\hline RV 'Alpha Helix', Dutch Harbor, Alaska: 28 September 1998 \\
On ship deck & 1.341 \\
0.15 & 1.100 \\
1.0 & 0.374 \\
2.0 & 0.108 \\
USCGC 'Polar Sea', St. Lawrence Island polynya: 21 April 1999 \\
On ship deck & 0.57 \\
0.1 & 0.578 \\
1 & 0.28 \\
2 & 0.13 \\
3 & 0.061 \\
4 & 0.030 \\
5 & 0.016 \\
6 & 0.0087 \\
\hline
\end{tabular}




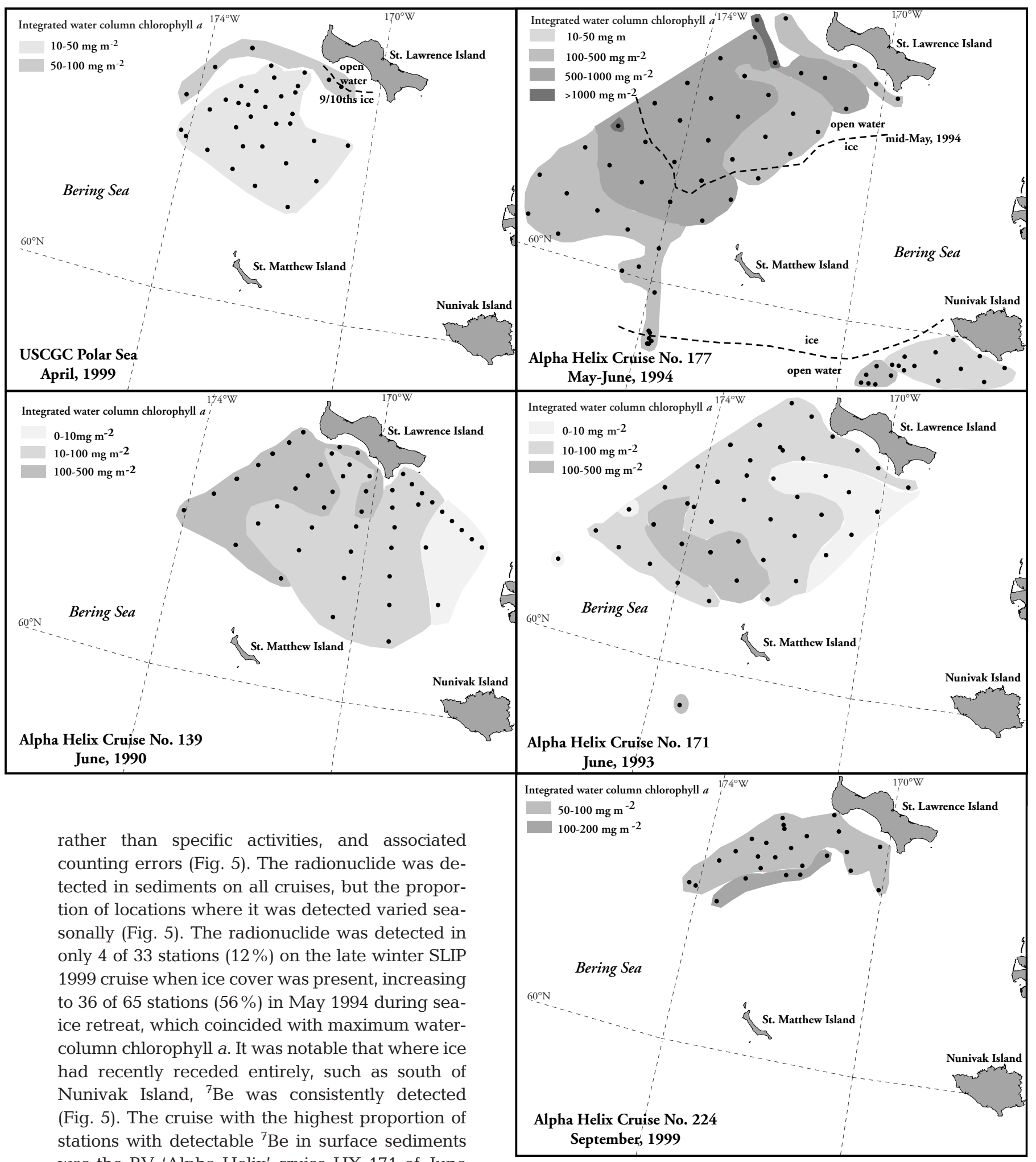
was the RV 'Alpha Helix' cruise HX 171 of June 1993, when the radionuclide was detected in 21 of 36 stations $(65 \%)$. By the time of the September 1998 cruise HX 214, detection of ${ }^{7} \mathrm{Be}$ in surface sediments had declined to only 8 of 24 stations (33\%).

Fig. 1. Integrated chlorophyll a concentrations $\left(\mathrm{mg} \mathrm{m}^{-2}\right)$ over the entire water column during 5 cruises for the seasonal period April to September in several different years. Dots indicate sampling stations 


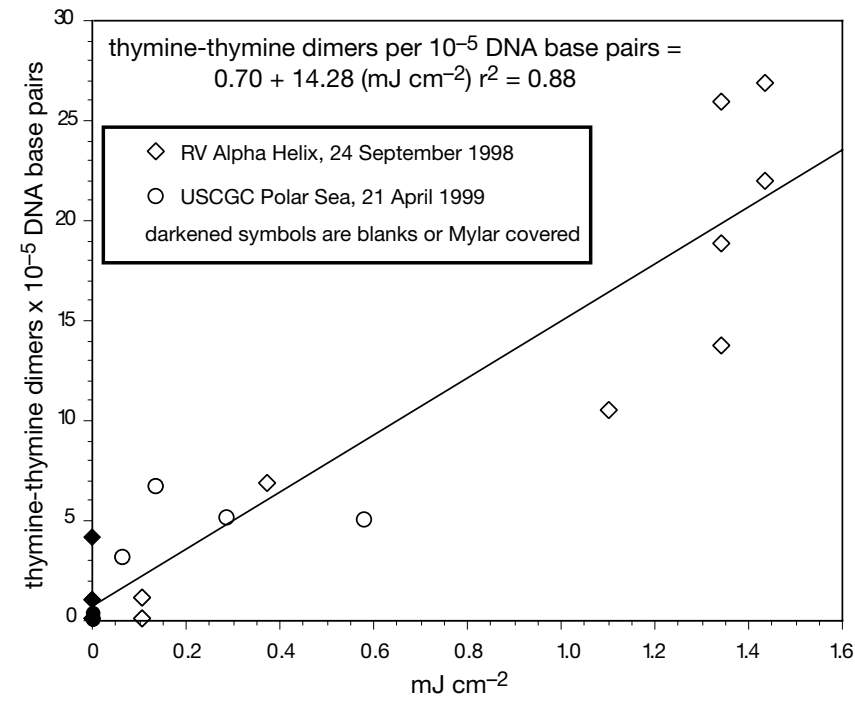

Fig. 2. Relationship between the number of DNA thyminethymine dimers formed during dosimeter deployment and the independent estimate of the DNA dose generated by integration of the radiation fluxes measured at each dosimeter depth during dosimeter deployment (Table 2). Recommendations of the instrument manufacturer (Biospherical Instruments 1997) and Dahlback (1996) were used to convert radiation flux measurements into estimated DNA doses

\section{Sediment chlorophyll a}

Concentrations of photosynthetically competent chlorophyll a deposited to surface sediments varied in much the same way (Fig. 6) that integrated water- column concentrations varied seasonally (Fig. 1). Sediment chlorophyll a concentrations were highest during the May, June 1994 cruise HX 177, and were much lower in the fall (September 1998 and 1999) and during April 1999 when the polynya was present.

\section{Sediment oxygen demand}

In core incubations, sediment oxygen respiration rates were highest during the June and July 1990 and June 1993 RV 'Alpha Helix' cruises and the 1988 BERPAC cruise, which operated in the early openwater season after ice retreat (Fig. 7). Lower rates were observed during the ice retreat in 1994, when water-column chlorophyll a was at a maximum, as well as in late summer and fall of 1993 and of 1998 and 1999. The lowest sediment respiration rates were observed during April 1999 under late-winter conditions (Fig. 7).

\section{Stable organic carbon isotope ratios of sediments}

The stable carbon isotope composition of organic matter isolated from surface sediments exhibited $\delta^{13} \mathrm{C}$ values ranging from -20 to $-22 \%$ (Fig. 8). There was no perceptible 'halo' of isotopically lighter carbon present in the sediments under or near the polynya, as would be expected were significant open-water production to occur while the polynya was present.

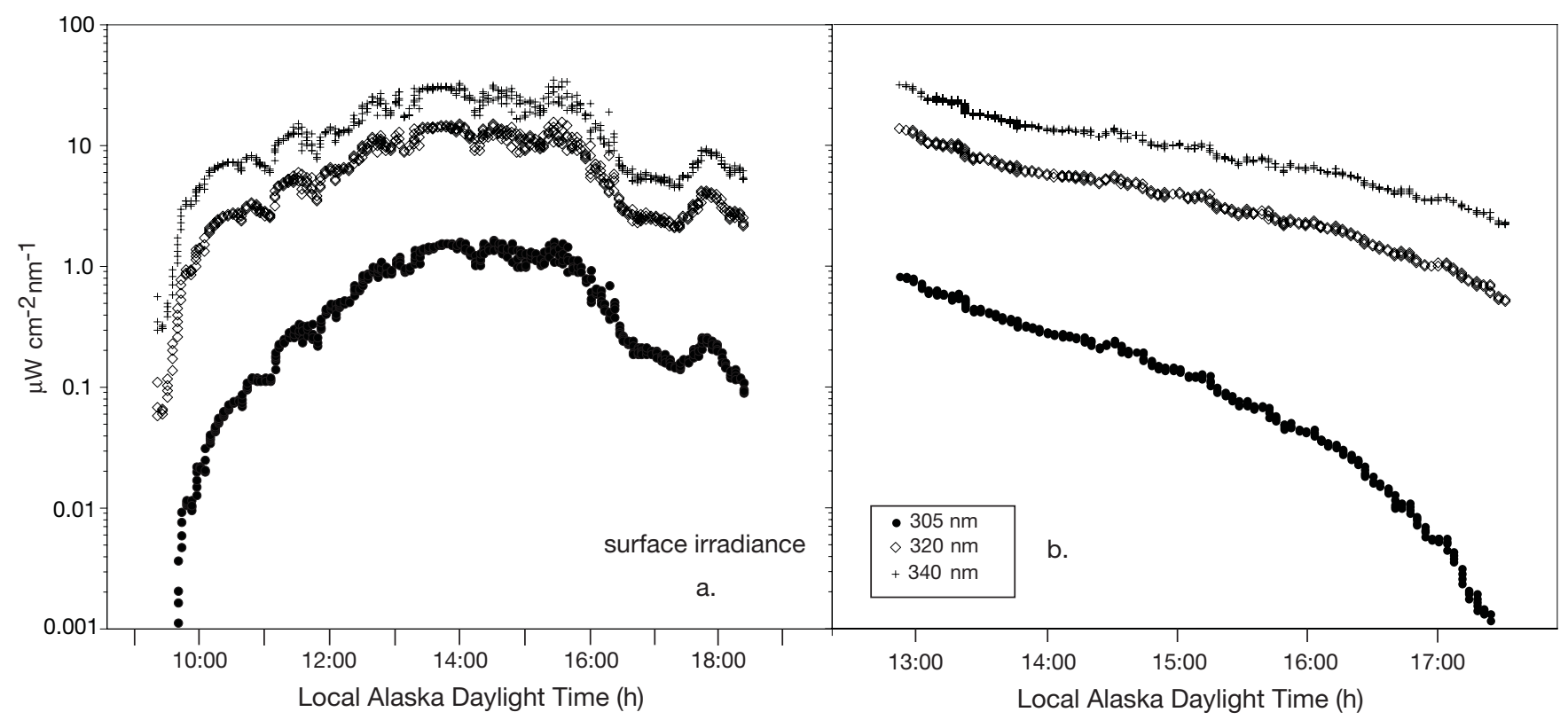

Fig. 3. Surface radiation fluxes at 3 wavelengths while ship was (a) anchored in Dutch Harbor, Alaska, 24 September 1998, and (b) while ship was on station in the polynya south of St. Lawrence Island, Bering Sea, 21 April 1999 


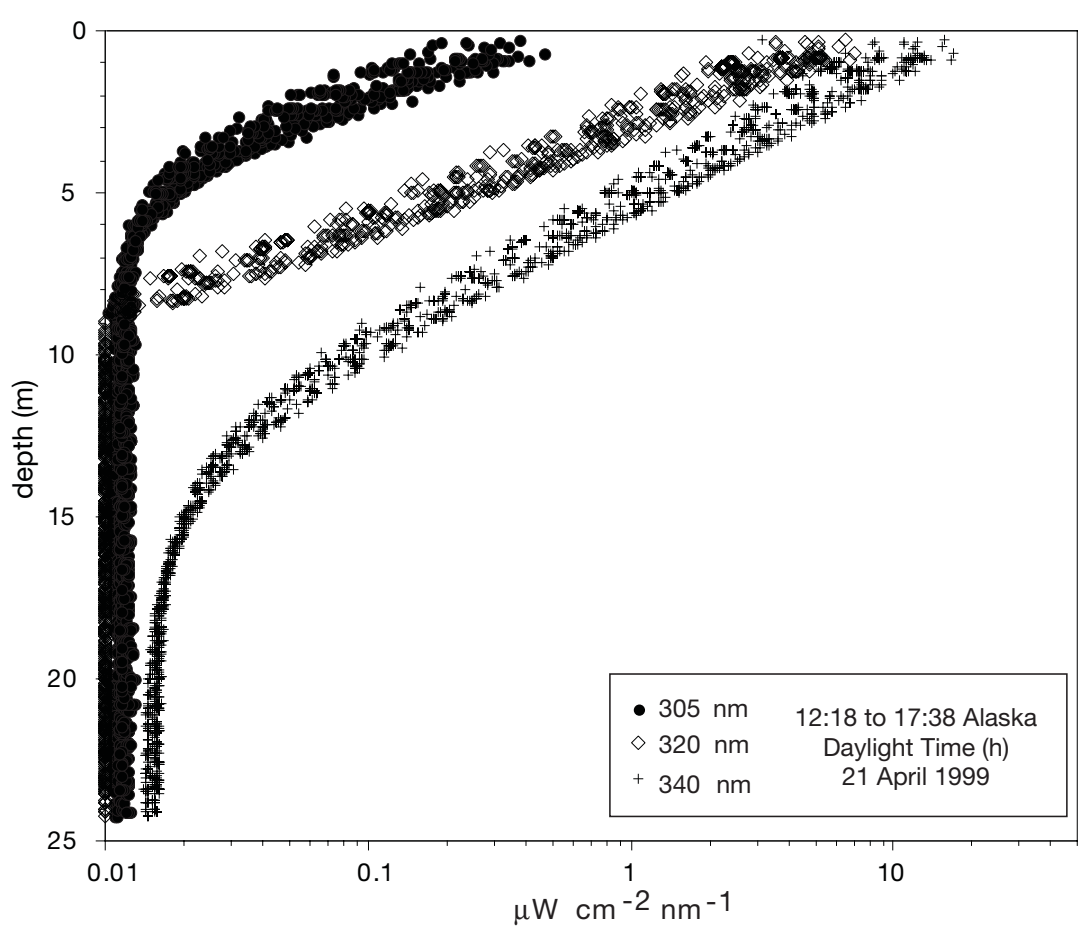

Fig. 4. Penetration of UV at 3 wavelengths within the water column while ship was on station in the polynya south of St. Lawrence Island, Bering Sea, 21 April 1999

\section{DISCUSSION}

Our measurements of UV radiation and DNA damage indicate that UV radiation probably did not inhibit primary production within the polynya during the late-winter period. UV-B doses we measured during spring and autumn in the Bering Sea are not large relative to other measurements in Antarctica or at more temperate latitudes. Surface irradiances in the UV-B band (290 to 320 $\mathrm{nm}$ ) at Palmer Station, Antarctica, during stratospheric ozone depletion in austral spring approach $100 \mu \mathrm{W} \mathrm{cm}{ }^{-2}$ (Karentz \& Lutze 1990), compared with maximum readings in a range of 1 to $10 \mu \mathrm{W} \mathrm{cm} \mathrm{cm}^{-2}$ (Figs 3,4) in the present study. Similarly, in single-day exposures of UV dosimeters in Melbourne, Florida, solar UV-B doses ranged from 500 to $1040 \mathrm{~mJ} \mathrm{~cm}^{-2}$ (Yoshida \& Regan 1997 ) relative to our estimates of $<1.5 \mathrm{~mJ} \mathrm{~cm}^{-2}$ for the Bering Sea waters we sampled (Fig. 2). Note that in making these comparisons we use the radiative transfer model of Dahlback (1996) to estimate the total UV dose across the 290 to $320 \mathrm{~nm}$ band. The relatively low irradiances we measured are very similar to irradiance levels at 305 and $340 \mathrm{~nm}$ measured in late winter at the Point Barrow long-term UV measurement site (Gurney 1998). These latter measurements and those at Palmer Station in Antarctica, were made with a high resolution Biospherical Instruments spectroradiometer, while our measurements were based on wider filter bands.
Our UV-B dose estimates are not entirely comparable to estimates in Antarctica or Florida if Arctic phytoplankton are significantly more sensitive to UV-B radiation. However, UV-B radiation at our open-ocean study site south of St. Lawrence Island dropped to negligible levels at depths greater than $5 \mathrm{~m}$ (Fig. 4). During some of our other oceanographic measurements in April 1999 near St. Lawrence Island, the water column was isothermal (ca $-1.8^{\circ} \mathrm{C}$ ), largely icecovered, and unstratified. Low concentrations of chlorophyll a were observed and were distributed homogeneously (Fig. 1). Thus, there were no apparent physical processes in the water column that would hold phytoplankton near the surface to facilitate UV-B exposure. Some UV impacts upon sea-ice algae in the predominant overlying ice are probably present, but it is difficult to quantify these impacts because of the inhomogeneous distribution of algae within sea ice. It is also probable that during the sea-ice retreat in the Bering Sea (May and June), with increasing solar radiation and icemelt stratification of surface waters, that impacts of UV upon biological processes are more likely.

Chlorophyll a concentrations during this study showed high seasonal variability (Fig. 1). Significantly, the lowest integrated chlorophyll a concentrations of any cruise were observed in April 1999 during the latewinter period when the polynya was present. The mean chlorophyll a concentration in all water samples on this cruise was $0.60 \mathrm{mg} \mathrm{m}^{-3} \pm 0.34 \mathrm{SD}(\mathrm{n}=394)$, with a maximum of $2.47 \mathrm{mg} \mathrm{m}^{-3}$. These low concentrations of chlorophyll $a$, integrated over the entire water column (Fig. 1), with most $<1 \mathrm{mg} \mathrm{m}^{-3}$, indicate that the phytoplankton standing stock during late winter is not likely to be an important component of annual benthic carbon deposition. In contrast, at the time of ice melt approximately 1 mo later (observations in May and June, 1994), chlorophyll a concentrations were as much as 3 orders of magnitude higher than in late winter when integrated over the whole water column. The standing stock of sediment chlorophyll a showed similar maxima during or just after the sea-ice melt, and minima in September and April (Fig. 6). Water-column chlorophyll a inventories remained relatively high (up to $500 \mathrm{mg} \mathrm{m}^{-2}$ ) later in the summer during the ice-free season (June 1990 and 1993), and declined in the fall (September 1999). The pattern that emerges from both the water-column (Fig. 1) and sediment (Fig. 6) measurements is of low chlorophyll standing stocks before 


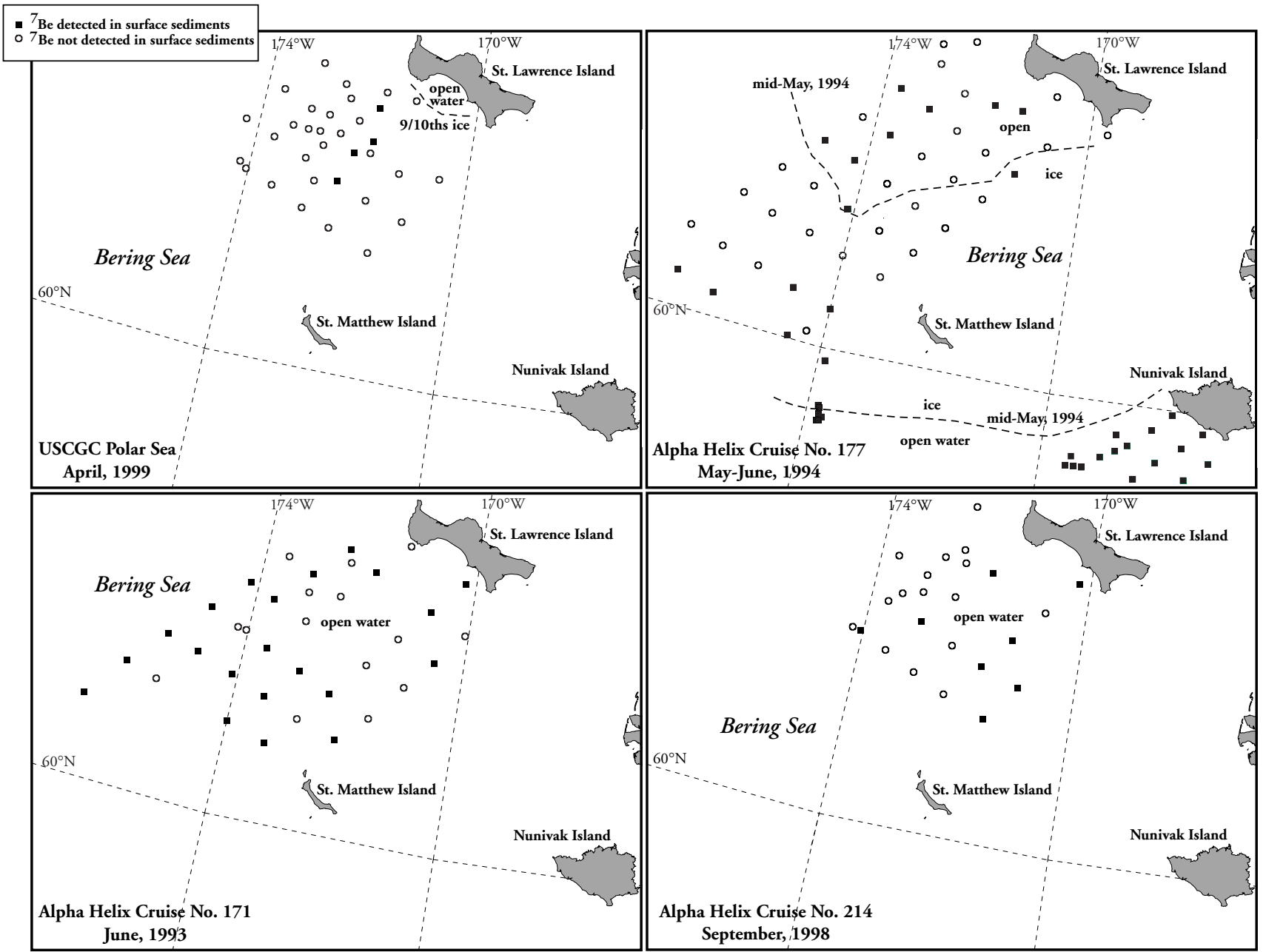

Fig. 5. Locations of surface sediments on 4 cruises where ${ }^{7}$ Be was detected and locations where sediments were collected and ${ }^{7}$ Be was not detected. Dashed lines show transition between open water and nine-tenths ice cover

the ice melt. During the ice melt, a large bloom is followed by progressive decreases in standing stock over the summer and fall. Given this fairly typical subarctic biological cycle in the water column, the short temporal time lag until the appearance of related markers in the sediment is not surprising.

For example, the detection of ${ }^{7} \mathrm{Be}$ was at a minimum in late winter (April 1999) when sea ice limits sedimentation of the radionuclide between its sole source in the atmosphere and the sea floor. Later, as the sea ice melted (May/June 1994), ${ }^{7}$ Be was much more readily detected, particularly in areas such as south of Nunivak Island, where ice had been absent for at least several weeks before our sampling (Fig. 5). However, the highest proportion of sediment samples in which the short-lived radionuclide was detected was in June 1993, several weeks after the ice retreat, when integrated chlorophyll a concentrations were lower than the maximum observed during the dissolution of ice in May and June 1994 (Fig. 1). Significantly, sediments collected during this cruise, immediately following the spring bloom, also had the highest mean ${ }^{7}$ Be activities of any cruise during this study (7.6 $\mathrm{Bq} \mathrm{kg}^{-1}$ ). Maximum water-column concentrations of chlorophyll a were also distributed higher in the water column in May and June 1994 (during the ice-melt) than in June 1993 (after the ice melt; data not shown). These patterns suggest that the maximum deposition of ${ }^{7} \mathrm{Be}$ occurred as the spring ice-melt bloom sank to the bottom. By the fall (September 1998), the proportion of stations where ${ }^{7} \mathrm{Be}$ was detected declined further, as did integrated chlorophyll a concentrations, sediment chlorophyll a standing stock, and oxygen respiration rates.

Sediment oxygen demand also appears to follow the pattern indicated by ${ }^{7} \mathrm{Be}$ detection. Maxima in sediment oxygen demand were observed after the ice-melt in June (Cruises HX 171 and HX 139: Fig. 7; see also Grebmeier \& Cooper 1995) rather than at the time of peak chlorophyll a concentrations in the water column (Fig. 1: HX 177, May and June 1994). This is likely to 


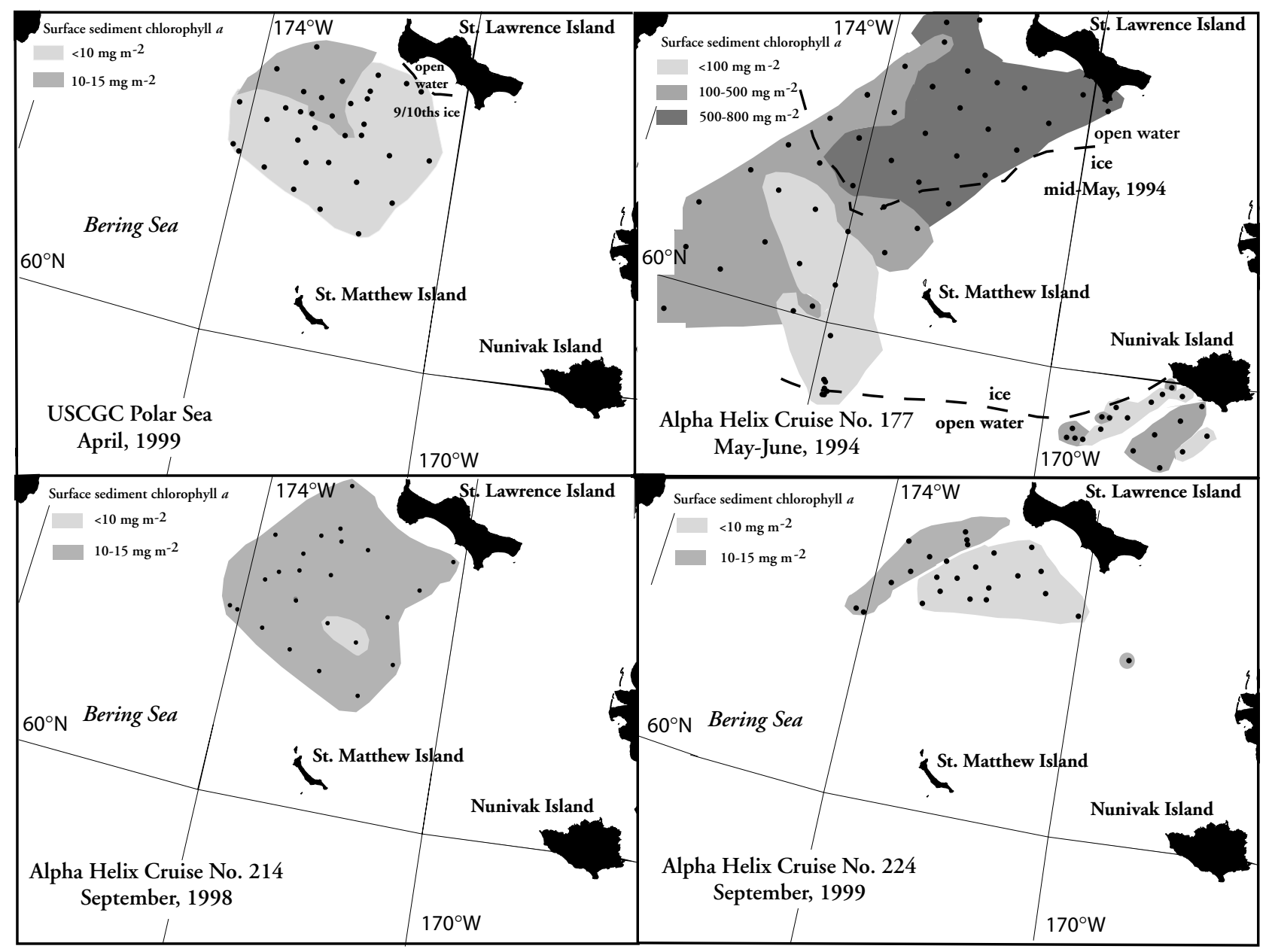

Fig. 6. Inventories of photosynthetically competent chlorophyll a $\left(\mathrm{mg} \mathrm{m}^{-2}\right)$ deposited to surface sediments on 4 cruises

be the result of the time lag of days to weeks for sedimentation of organic material (and ${ }^{7} \mathrm{Be}$ ) to the surface sediments. Very low oxygen respiration rates in April and low rates in September 1998 and 1999 indicate that these are periods of the year without a high sedimentation of organic material to the benthos.

Our measurements of stable carbon isotope ratios in the organic carbon of surface sediments did not show an area of more negative $\delta^{13} \mathrm{C}$ values under the polynya; this could have been associated with production in the open waters of the polynya (Fig. 8). Instead, our data are consistent with the conclusions of a recent survey of $\delta^{13} \mathrm{C}$ values of surface sediments from a wide area across the Amerasian Arctic (Naidu et al. 2000) that sediment organic $\delta^{13} \mathrm{C}$ values observed over the seasonally ice-free Bering, Chukchi, Beaufort, and East Siberian shelves are predominantly controlled by terrestrial contributions of organic carbon effects (see discussion in Naidu et al. 2000) and by kinetic isotope effects associated with pelagic primary production (see, for example, discussions in Fry 1996, Rau et al. 1997, Korb et al. 1998, and Riebesell et al. 2000). In the context of these data, it is also possible to conclude that production of sea-ice algae is not crucial in determining the stable carbon isotope composition of organic material deposited on the sea floor in this region. Ice algae collected in the northern Bering Sea during our April 1999 cruise exhibited $\delta^{13} \mathrm{C}$ values significantly less negative than those typical of high-latitude, openwater production $\left(\delta^{13} \mathrm{C}\right.$ range from -9.6 to -22.1 ; average $=-12.8 \pm 6.2 \mathrm{SD}_{;} \mathrm{n}=8$ : Lovvorn unpubl. data). In comparison, open-water particulate organic matter collected south of our study area in the middle shelf of the Bering Sea, remote from coastal influences, had $\delta^{13} \mathrm{C}$ values of -21.7 to $-25.2 \%$ (Wainwright et al. 1998). A slight increase in $\delta^{13} \mathrm{C}$ values is often observed between primary and secondary producers in marine systems (del Giorgio \& France 1996). However, Schell et al. (1998) reported $\delta^{13} \mathrm{C}$ of -20 to $-26 \%$ for copepods in this region of the Bering Sea. The geographical vari- 


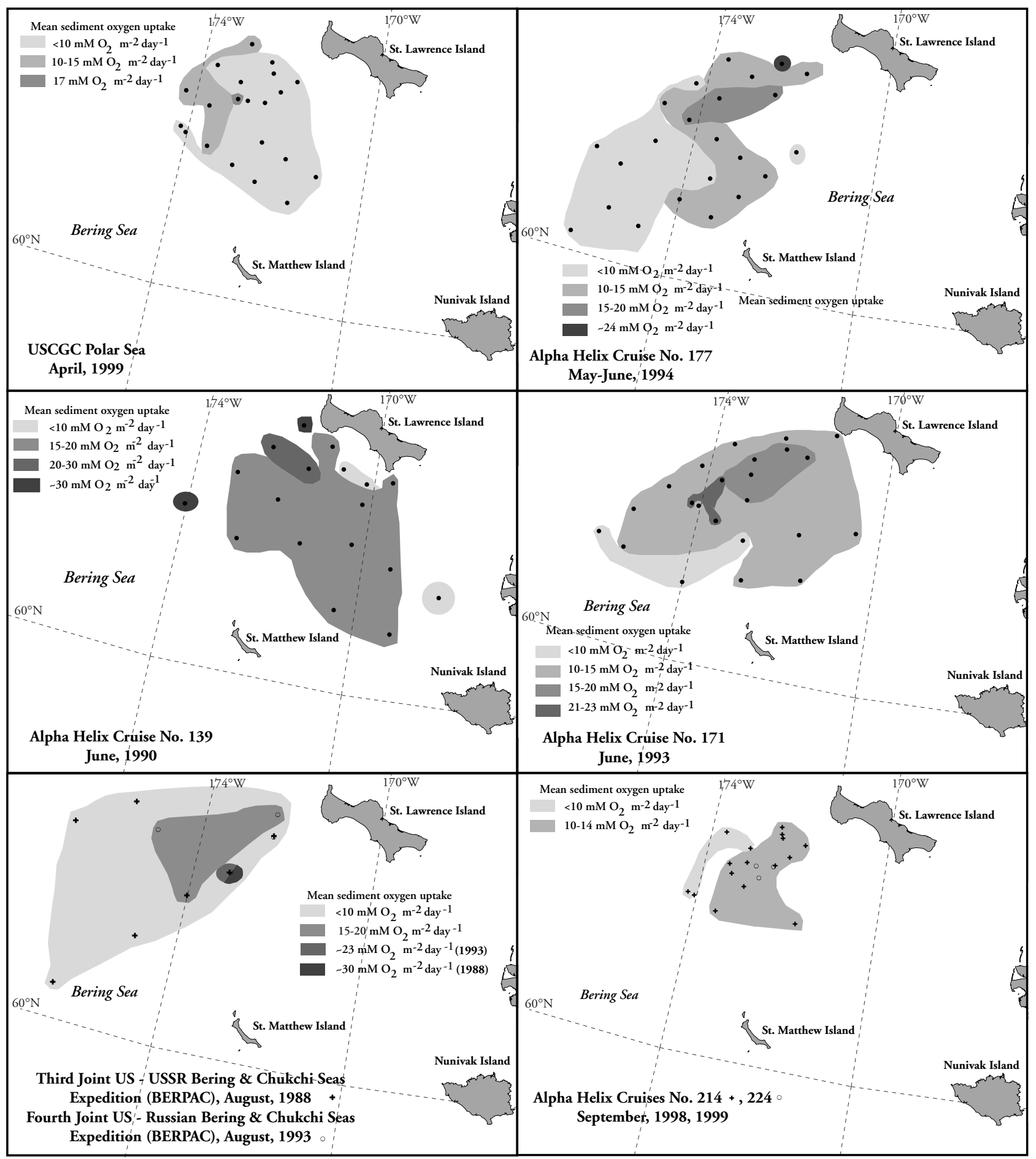

Fig. 7. Seasonal sediment oxygen uptake $\left(\mathrm{mM} \mathrm{m}^{-2} \mathrm{~d}^{-1}\right)$ as an indicator of carbon flux to the sediments for the region south of St. Lawrence Island (April to September over the period 1988 to 1999)

ation pattern reported is very similar to the west-toeast decrease in $\delta^{13} \mathrm{C}$ values observed for sediment organic matter (Fig. 8; see also Naidu et al. 2000). Saupe et al. (1989) also reported stable carbon isotope ratios for organic matter in copepods $(-20.9 \pm 0.8)$ that match sediment organic carbon in the northern Bering Sea. While there is no evidence for an umbra of relatively negative $\delta^{13} \mathrm{C}$ values associated with open-water production in the polynya, we cannot use the stable carbon isotope composition of sediment organic matter 


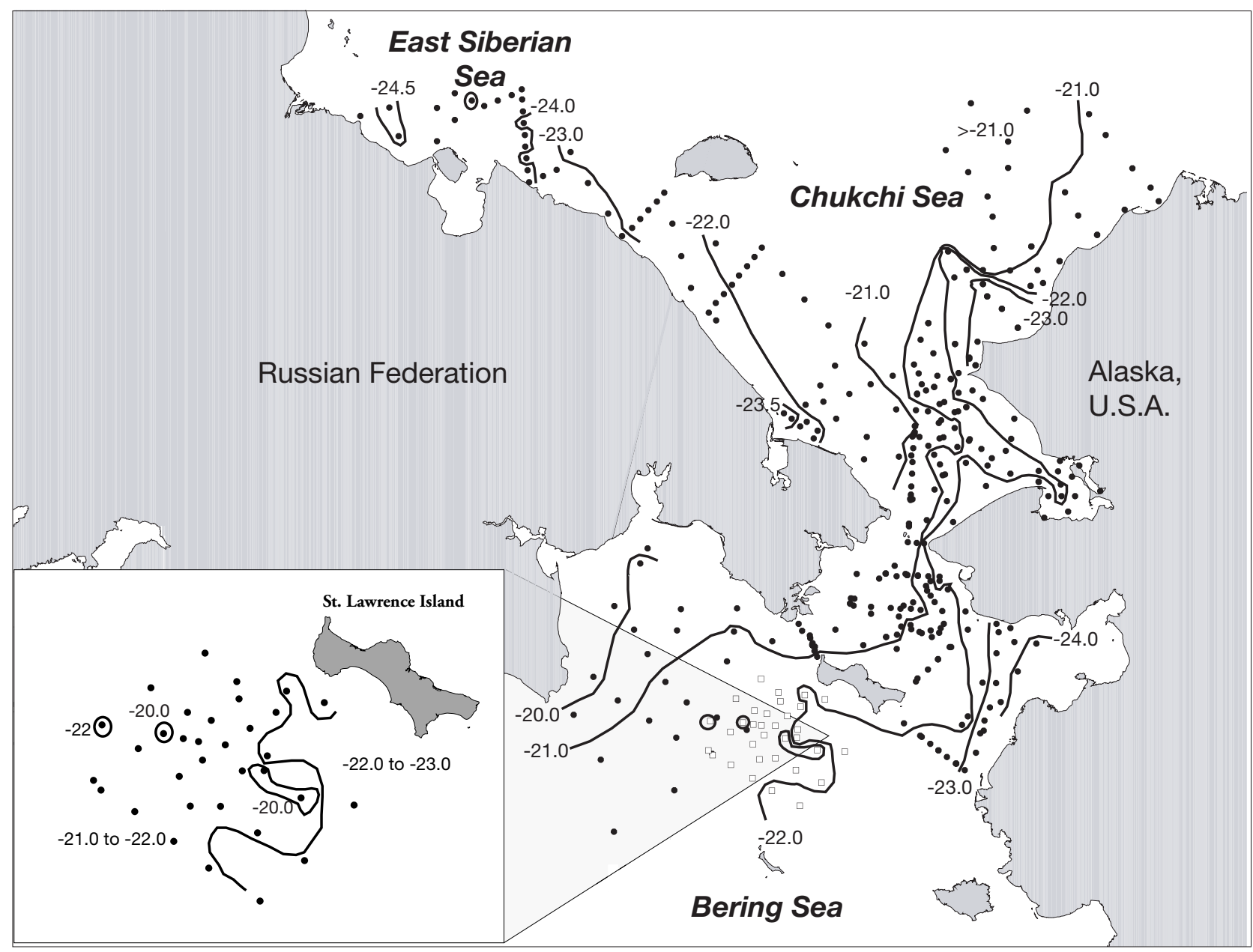

Fig. 8. Stable carbon isotope composition $\left(\delta^{13} \mathrm{C}_{\mathrm{V}-\mathrm{PDB}}\right)$ of surface sediments in the Bering, Chukchi, and East Siberian Seas (modified from Naidu et al. 2000). (ㅁ) new data (this study); inset shows these additional data for region south of St. Lawrence Island

by itself to conclude that production and resulting deposition in the polynya is low. The west-to-east decrease in $\delta^{13} \mathrm{C}$ over the whole Bering Sea region is therefore probably a function of the proximity of Alaskan rivers, which contribute terrestrial carbon with lower $\delta^{13} \mathrm{C}$ values. It is also likely that kinetic isotopic effects during primary production are at least as significant, as higher primary production (and less isotopic fractionation) can be expected on the western side of the Bering Sea as a result of higher nutrient concentrations.

\section{Conclusions}

The northern Bering and southern Chukchi shelves probably support the highest benthic biomass in the Arctic (Highsmith \& Coyle 1990, Grebmeier et al. 1995). The productivity of these benthic communities is largely a function of high water-column productivity (Walsh et al. 1989, Springer et al. 1996). To some extent, the presence of polynyas, such as that which recurs annually south of St. Lawrence Island during the ice-covered winter months, may influence the re-distribution of organic carbon particles during brine formation events that resuspend flocculent organic matter. However, during our cruise in April 1999, we found little evidence that the presence of open water south of St. Lawrence Island during the late winter period is itself a source of biogenic material. Chlorophyll a concentrations are uniformly low, and indicators of recent organic sedimentation $\left({ }^{7} \mathrm{Be}\right.$ detectability, oxygen respiration rates, and sediment chlorophyll a concentrations) were also at annual minima compared to measurements made in the spring, summer and fall months between May and September. $\delta^{13} \mathrm{C}$ values of surface sediment organic carbon do not suggest that there is any localized region of open-water production near the polynya. These indications of low phytoplankton biomass in April do not appear to be a function of UV irradiance. Although actual DNA damage 
in molecular dosimeters was correlated with DNA damage estimated from irradiance measurements, overall irradiance was low. No significant UV irradiance extended below $5 \mathrm{~m}$ depth, and an homogeneous, wellmixed water column did not facilitate retention of phytoplankton cells within the upper surface water layers where UV damage could have occurred.

Water-column and recent sedimentation indicators suggest an annual pattern of sedimentation on this northern Bering shelf that is strongly linked to the timing of the sea-ice melt. Chlorophyll a concentrations were at a study maximum during sea-ice dissolution in May 1994. Sedimentation of this biomass happened shortly afterwards, as indicated by maximal ${ }^{7} \mathrm{Be}$ detectability, oxygen respiration rates, and sediment chlorophyll a concentrations for this study in June 1990 (Grebmeier \& Cooper 1995) and June 1993. Later in the summer season (data from August 1993 and September 1998 and 1999), the water-column and sedimentation indicators we used all declined in intensity. All observations in April 1999 are consistent with prebloom conditions, despite the presence of open water and thin ice associated with the St. Lawrence Island polynya.

Acknowledgements. We thank the captains, crews, and many individual members of the scientific parties aboard the MV 'Akademik Korolev', RV 'Alpha Helix', MV 'OKEAN', and USCGC 'Polar Sea' for their assistance in sampling. Participation in the Joint Russian US Expeditions to the Bering Sea was supported through the 'BERPAC' program, under the auspices of the Russia US Environmental Agreement. This joint Russian US work in the Bering Sea would not have been possible without the efforts of Steve Kohl, Peter Ward, and Hal O'Connor of the US Fish and Wildlife Service. The acquisition of the UV instrumentation used in this work was supported by the Office of Biological and Ecological Research of the US Department of Energy. Other financial support was provided by several grants from the Office of Polar Programs of the US National Science Foundation. We thank 4 anonymous reviewers who provided constructive criticisms on an earlier version of this manuscript.

\section{LITERATURE CITED}

Ambrose WG Jr, Renaud PE (1995) Benthic response to water column productivity patterns: evidence for benthic-pelagic coupling in the Northeast Water polynya. J Geophys Res 100(C3):4411-4421

Biospherical Instruments (1997) Application note: GUV 'DNA dose' calculations. Biospherical Instruments, Inc., San Diego, CA

Carrier WL, Setlow RB (1970) Endonuclease from Micrococcus luteus which has activity towards ultraviolet-irradiated dexoyribonucleic acid: purification and properties. J Bacteriol 102:178-186

Cooney RT, Coyle KO (1982) Trophic implications of crossshelf copepod distributions in the southeastern Bering Sea. Mar Biol 70:187-196
Cooper LW, Grebmeier JM, Larsen IL, Dolvin S, Reed AJ (1998) Inventories and distribution of radiocaesium in arctic marine sediments: influence of biological and physical processes. Chem Ecol 15:27-46

Cooper LW, Cota GF, Pomeroy LR, Grebmeier JM, Whitledge TE (1999) Modification of NO, PO, and NO/PO during flow across the Bering and Chukchi shelves: implications for use as Arctic water mass tracers. J Geophys Res 104: $7827-7836$

Coyle KO, Cooney RT (1988) Estimating carbon flux to pelagic grazers in the ice-edge zone of the eastern Bering Sea. Mar Biol 98:299-306

Dahlback A (1996) Measurements of biologically effective UV doses, total ozone abundances, and cloud effects with multichannel, moderate bandwidth filter instruments. Appl Optics 35:6514-6521

Dayton PK, Oliver JS (1977) Antarctic soft-bottom benthos in oligotrophic and eutrophic environments. Science 197(4298):55-58

Dayton PK, Watson D, Palmisano A, Barry JP, Oliver JS, Rivera D (1986) Distribution patterns of benthic microalgal standing stock at McMurdo Sound, Antarctia. Polar Biol 6:207-213

del Giorgio PA, France RL (1996) Ecosystem-specific patterns in the relationship between zooplankton and POM or microplankton $\delta^{13} \mathrm{C}$. Limnol Oceanogr 41:359-365

Fay FH, Feder HM, Stoker SW (1977) An estimation of the impact of the Pacific walrus population on its food resources in the Bering Sea. Marine Mammal Commission, Washington, DC (Final Report, Contracts MM4AC006 and MM5AC-024)

Feder HM, Jewett SC (1981) Feeding interactions in the eastern Bering Sea with emphasis on the benthos. In: Hood DW, Calder JA (eds) The Eastern Bering Sea Shelf: oceanography and resources. Vol. 20, Office Marine Pollution Assessment. NOAA. University of Washington Press, Seattle, p 1229-1261

Freeman SE, Blackett AD, Montelone DC, Setlow RB, Sutherland BM, Sutherland JC (1986) Quantitation of radiation-, chemical-, or enzyme-induced single-strand breaks in nonradioactive DNA by alkaline gel electrophoresis: application to pyrimidine dimers. Anal Biochem 158:119-129

Fry B $(1996){ }^{13} \mathrm{C} /{ }^{12} \mathrm{C}$ fractionation by marine diatoms. Mar Ecol Prog Ser 134:283-294

Gilchrist HG, Robertson GJ (2000) Observations of marine birds and mammals wintering at polynyas and ice edges in the Belcher Island, Nunavut, Canada. Arctic 53:61-68

Grebmeier JM, Cooper LW (1995) Influence of the St. Lawrence Island polynya upon the Bering Sea benthos. J Geophys Res 100:4439-4460

Grebmeier JM, Harrison NM (1992) Seabird feeding on benthic amphipods facilitated by gray whale activity in the northern Bering Sea. Mar Ecol Prog Ser 80:125-133

Grebmeier JM, McRoy CP (1989) Pelagic-benthic coupling on the shelf of the northern Bering and Chukchi Seas. III. Benthic food supply and carbon cycling. Mar Ecol Prog Ser 53:79-91

Grebmeier JM, Smith WO, Conover RJ (1995) Biological processes on Arctic continental shelves: ice-ocean-biotic interactions. In: Smith WO, Grebmeier JM (eds) Arctic oceanography: marginal ice zones and continental shelves. American Geophysical Union, Washington, DC, p 231-261

Gurney KR (1998) Evidence for increasing ultraviolet irradiance at Point Barrow, Alaska. Geophys Res Lett 25: 903-906

Highsmith RC, Coyle KO (1990) High productivity of north- 
ern Bering Sea amphipods. Nature (Lond) 344:862-864 Highsmith RC, Coyle KO (1992) Productivity of arctic amphipods relative to gray whale energy requirements. Mar Ecol Prog Ser 83:141-150

Hobson KA, Ambrose WG Jr, Renaud PE (1995) Sources of primary production, benthic-pelagic coupling, and trophic relationships within the northeast water polynya: insights from $\delta^{13} \mathrm{C}$ and $\delta^{15} \mathrm{~N}$ analysis. Mar Ecol Prog Ser 64:1-10

Kanneworff E, Nicolaisen W (1973) The 'HAPS': a frame supported bottom sampler. Ophelia (Suppl) 10:119-129

Karentz D, Lutze LH (1990) Evaluation of biologically harmful ultraviolet radiation in Antarctica with a biological dosimeter designed for aquatic environments. Limnol Oceanogr 35:549-561

Kirk JTO, Hargreaves BR, Morris DP, Coffin RB, and 9 others (1994) Measurements of UV-B radiation in two freshwater lakes: an instrument comparison. Arch Hydrobiol Suppl 43:71-99

Korb RE, Raven JA, Johnston AM (1998) Relationship between aqueous $\mathrm{CO}_{2}$ concentrations and stable carbon isotope discrimination in the diatoms Chaetoceros calcitrans and and Ditylum birghtwellii. Mar Ecol Prog Ser 171: 303-305

Massom RA (1988) The biological significance of open water within the sea ice cover of the polar regions. Endeavour 12:21-26

Naidu AS, Cooper LW, Finney BP, Macdonald RW, Alexander C, Semiletov IP (2000) Organic carbon isotope ratios $\left(\delta^{13} \mathrm{C}\right)$ of arctic Amerasian continental shelf sediments. Int J Earth Sci 89:522-531

Olsen CR, Larsen IL, Lowry PD, Cutshall NH (1986) Geochemistry and depositon of ${ }^{7} \mathrm{Be}$ in river-estuarine and coastal waters. J Geophys Res 91:869-908

Petersen MR, Piatt JF, Trust KA (1998) Foods of spectacled eiders Somateria fischeri in the Bering Sea, Alaska. Wildfowl 49:124-128

Rau GH, Sullivan CW, Gordon LI (1991) $\delta^{13} \mathrm{C}$ and $\delta^{15} \mathrm{~N}$ variations in Weddell Sea particulate organic matter. Mar Chem 35:355-369

Rau G(H), Riebesell U, Wolf-Gladrow D (1997) $\mathrm{CO}_{2 \mathrm{aq}}$-dependent photosynthetic ${ }^{13} \mathrm{C}$ fractionation in the ocean: a model versus measurements. Global Biogeochem Cycles 11: 267-278

Regan JD, Carrier WL, Gucinski H, Olla BL, Yoshida H, Fujimura RK, Wicklund RI (1992) DNA as a solar dosimeter in the ocean. Photochem Photobiol 56:35-42

Editorial responsibility: Otto Kinne (Editor),

Oldendorf/Luhe, Germany
Riebesell U, Burkhardt S, Dauelsberg A, Kroon B (2000) Carbon isotope fractionation by a marine diatom: dependence on the growth-rate-limiting resource. Mar Ecol Prog Ser 193:295-303

Saupe SM, Schell DM, Griffiths WB (1989) Carbon-isotope ratio gradients in western arctic zooplankton. Mar Biol 103:427-432

Schell DM, Barnett BA, Vinette KA (1998) Carbon and nitrogen isotope ratios in zooplankton of the Bering, Chukchi and Beaufort Seas. Mar Ecol Prog Ser 162:11-23

Setlow RB (1974) The wavelengths in sunlight effective in producing skin cancer: a theoretical analysis. Proc Natl Acad Sci USA 71:3363-3366

Smith SD, Muench RD, Pease CH (1990) Polynyas and leads: an overview of physical processes and environment. J Geophys Res 95:9461-9479

Smith WO, Gordon LI (1997) Hyperproductivity of the Ross Sea (Antarctica) polynya during austral spring. Geophys Res Lett 24:233-236

Solovieva DV (1999) Spring stopover of birds on the Laptev Sea polynya. In: Kassens H, Buch HA, Dmitrenko I, Eicken $\mathrm{H}$, and 4 others (eds) Land-ocean systems in the Siberian arctic: dynamics and history. Springer-Verlag, Berlin, p 189-195

Springer AM, McRoy CP, Flint MV (1996) The Bering Sea green belt: shelf-edge processes and ecosystem production. Fish Oceanogr 5:205-223

Stirling I (1997) The importance of polynyas, ice edges, and leads to marine mammals and birds. J Mar Syst 10:9-21

Stringer WJ, Groves JE (1991) Location and areal extent of polynyas in the Bering and Chukchi Seas. Arctic 44: 164-171

Wainwright SC, Haney JC, Kerr C, Golovkin AN, Flint MV (1998) Utilization of nitrogen derived from seabird guano by terrestrial and marine plants at St. Paul, Pribilof Islands, Bering Sea, Alaska. Mar Biol 131:63-71

Walsh JJ, McRoy CP, Coachman LK, Goering JJ and 17 others (1989) Carbon and nitrogen cycling within the Bering/Chukchi Seas: source regions for organic matter effecting AOU demands of the Arctic Ocean. Prog Oceanogr 22:277-359

Welschmeyer NA (1994) Fluorometric analysis of chlorophyll $a$ in the presence of chlorophyll $b$ and pheopigments. Limnol Oceanogr 39:1985-1992

Yoshida H, Regan JD (1997) UVB DNA dosimeters analyzed by polymerase chain reactions. Photochem Photobiol 66:82-88

Submitted: October 26, 2000; Accepted: March 15, 2001

Proofs received from author(s): January 22, 2002 